\title{
TRACER STUDIES CONDUCTED NEARLY TWO DECADES APART ELUCIDATE GROUNDWATER MOVEMENT THROUGH A KARST AQUIFER IN THE FREDERICK VALLEY OF MARYLAND
}

\author{
Keith A. White \\ ARCADIS, 6723 Towpath Road, Syracuse, New York, 13214, U.S.A., keith.white@arcadis-us.com \\ Thomas J. Aley \\ Ozark Underground Laboratory, 1572 Aley Lane, Protem, Missouri, 65733, U.S.A., taley@ozarkundergroundlab.com \\ Michael K. Cobb \\ ARCADIS, 482 Congress Street, Suite 501, Portland, Maine, 04101, U.S.A., michael.cobb@arcadis-us.com
}

\author{
Ethan O. Weikel \\ U.S. Army Corps of Engineers, 10 South Howard Street, Baltimore, Maryland, 21201, U.S.A., \\ Ethan.O.Weikel@usace.army.mil
}

Shiloh L. Beeman

Ozark Underground Laboratory, 1572 Aley Lane, Protem, Missouri, 65733, U.S.A., shiloh@ozarkundergroundlab.com

\begin{abstract}
A pair of groundwater tracer studies at a single karst test site were completed 18 years apart. The results of these studies have provided evidence of both relatively rapid advective transport via conduits and an extreme capacity for dye storage and retardation. The tracer results, coupled with other subsurface investigation data, are used to develop a conceptual model for groundwater movement through this karst aquifer in the Frederick Valley of Maryland, as well as identify implications for remediation.
\end{abstract}

Three fluorescent tracer dyes used in the initial study were detected in several background monitoring locations established for the second study conducted 18 years later; demonstrating the persistence of these dyes in the aquifer. One of these dyes was not detected during the original study, providing useful information regarding flow and transport in the aquifer. At some of these sampling locations, at least one of the dyes was degraded, and would have gone undetected without the use of activated carbon samplers. Lastly, even though relatively rapid first detections occurred during both studies (as compared to non-karst groundwater systems) the majority of injected dye mass remained in the aquifer after the studies were completed. This suggests that the aquifer has a large capacity to store contaminants and that low levels of contaminants can be expected to persist in groundwater discharged from springs for a long period of time.

\section{Introduction}

The Frederick Valley lies near the western edge of the Piedmont Physiographic Province of Maryland. The Frederick Valley stretches northeastward from the Potomac River for $36 \mathrm{~km}$ (22 mi) and is composed of Cambrian and Ordovician carbonate rocks that are generally overlain by Triassic rocks that were deposited in two basins: the Culpeper basin to the south and the Gettysburg basin to the north. These two basins are separated by a narrow region where the Triassic rocks are absent. The Frederick Valley is bounded to the east by the regional Martic fault that juxtaposes low-grade metamorphic phyllites against the Paleozoic carbonates (Southworth, 1996). To the west, the Valley abuts the clastic rocks of the mountains of Maryland's Blue Ridge Physiographic Province. The southward-flowing Monocacy River drains the Valley.

The Frederick Valley represents Maryland's second largest karst terrane (Brezinski and Reger, 2002). The most common karst features are dolines (closed depressions), a subset of which are active sinkholes, and springs. Caves are rare in the Frederick Valley.

The tracer studies described herein were conducted to investigate the nature of groundwater movement near several former waste-disposal areas and identify associated groundwater discharge points. The 1995 study focused on shallow groundwater, with dyes mostly injected at or near the bedrock surface. The 2013 study focused on 
deeper intervals in the aquifer, with dyes injected into wells that intercepted solution porosity at two different depth intervals, many meters below the water table.

\section{Study Area Description}

The study area for this paper is located along the southern edge of the of the Gettysburg basin, at the west side of the Frederick Valley (Figure 1). The topography of the area is gently rolling and is cut by a series of small streams that drain into Carroll Creek. Carroll Creek is the principal tributary in the area and flows generally southeastward, eventually joining the Monocacy River southeast of the study area. Several springs are located along Carroll Creek.

The southeastern portion of study area is underlain by fractured limestones and dolomites of the Cambrian Frederick Formation. These rocks are underlain by sandstones and siltstones of the Araby ( $\mathrm{Car}$, middle-lower Cambrian) and Antietam ( $\mathrm{Ca}$, lower Cambrian) Formations. The northeastern portion of the study area is underlain by the Triassic New Oxford Formation of the Gettysburg basin.

\section{Lithology}

The Frederick Formation is divided into several members. The member that directly underlies the study area is the Rocky Springs Station Member ( $C f r)$. It is characterized as dark gray, very thinly bedded, lime mudstone interbedded and interlaminated with black, calcareous shale. This lithology is interbedded with intervals of

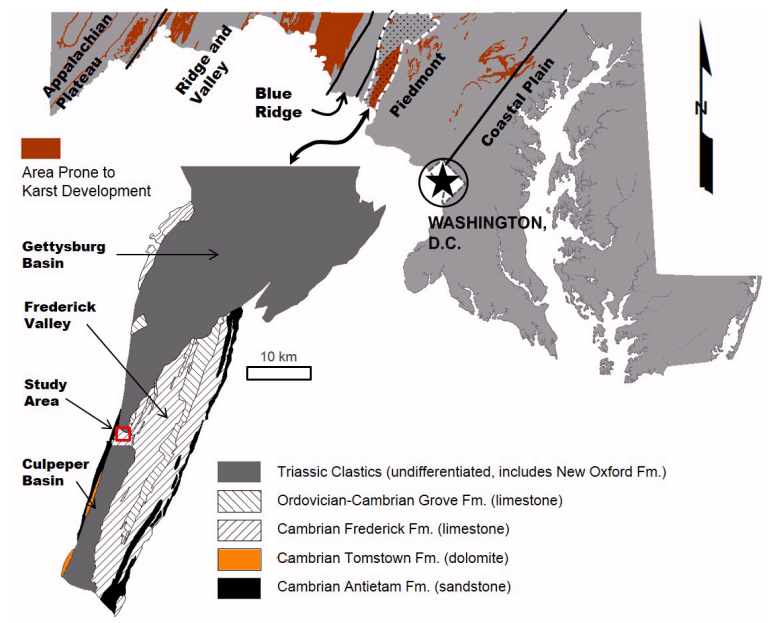

Figure 1. Location map of the karst regions of Maryland, bedrock geology of the Frederick Valley, and location of the study area. Modified from Brezinski and Reger (2002). very thick to massively bedded limestone breccia that includes various limestone lithologies and sandy limestone. The thickness of the member beneath the study area is estimated to exceed $300 \mathrm{~m}(1,000 \mathrm{ft})$ (Brezinski 2004a; 2004b).

The New Oxford Formation is characterized by brownish red to reddish gray, and locally greenish gray sandstone, interbedded with red claystone $(T n)$ with a conglomerate $(T n c)$ at its base. Beneath the study area, the conglomerate is composed of pebbles and some cobbles of white and gray limestone in a fine-grained red matrix with calcite cement. The thickness of the unit is unknown (Brezinski 2007).

\section{Structure}

Rocks in the region have been tightly folded and faulted; however, bedrock exposures in the Valley are rare. The study area is located on the western limb of the Frederick Valley Synclinorium, whose axis is approximately 5.5 $\mathrm{km}(3.5 \mathrm{mi})$ to the east. Bedding in the Rocky Springs Station Member near the study area generally dips toward the southeast, with dip angles ranging from 25 to 75 degrees. Geophysical logging of boreholes in the study area shows considerable local structural variability, particularly near unit contacts. Bedding in the New Oxford Formation has an approximate strike of $\mathrm{N} 10^{\circ}$ $\mathrm{W}$ and dips to the west-southwest at approximately $30^{\circ}$ near the study area (Brezinski, 2004b).

Little information is available regarding jointing in the Frederick or New Oxford Formations near the study area. In his study of the Frederick and Hagerstown Valleys, Nutter (1973) noted that a joint set parallel to the strike of the bedding is almost always present, as is a near vertical set with a strike that is nearly normal to the bedding strike. Brezinski (2004a) reports that jointing in the Grove Formation (late Cambrian-early Ordovician), which overlies the Frederick Formation, has a pervasive joint system with a primary orientation of $\mathrm{N} 72^{\circ} \mathrm{W}$, and a secondary set oriented $\mathrm{N} 20^{\circ}$ E. Jointing mapped in the Triassic Leesburg Formation during the same study exhibits a completely different trend with the main trend oriented $\mathrm{N} 87^{\circ} \mathrm{E}$ and a conjugate set oriented $\mathrm{N} 45^{\circ} \mathrm{W}$. The Frederick and New Oxford Formations are truncated along the northwestern edge of the study area by the steeply-dipping Bull Run Mountain Fault. The study area is on the downthrown side of the fault. Across the fault are younger clastic rocks of the Antietam Formation. Faults are expected to be more extensive and numerous in the region than is shown on published maps because very detailed mapping is required to locate all but the largest and most obvious (Nutter, 1973). 


\section{Karst Development}

Studies related to karst development in the Frederick Valley focus on the occurrence and availability of groundwater in bedrock (Nutter, 1973) and susceptibility to sinkhole formation (Brezinski and Reger, 2002; Brezinski 2004a; Brezinski 2007).

Nutter (1973) believed joints to be the most important factor in controlling the formation of solution channels, and that solution activity decreased with depth. He also notes that solution cavities are apparently rare below a depth of $90 \mathrm{~m}$ (300 ft). It should be noted, however, that he provides little region-specific information to substantiate these statements.

Brezinski and Reger (2002) and Brezinski (2004a) examined the nature and distribution of karst features (closed depressions, active collapse sinkholes ${ }^{1}$, and springs) in the eight main carbonate rock units of the Frederick Valley. For the Rocky Springs Station Member, which underlies much of the study area, they found its susceptibility to karst formation to be low-to-moderate. They

${ }^{1}$ Brezinski (2004a) identified active sinkholes as typically having an open throat and/or steep, unvegetated sides that suggest recent activity. attributed the relatively low susceptibility to the thinbedded, shaly nature of the member. The other carbonate formation that underlies the study area, the New Oxford Conglomerate, was not included in the above studies.

\section{Approach}

Fluorescent dyes and activated carbon samplers (supplemented with groundwater grab samples) were employed in both studies. During each sampling event, activated carbon samplers were collected for analysis and replaced with a fresh sampler. A grab water sample was also collected at each location during each event; but analyzed only selectively to confirm where dye had been detected in the activated carbon sampler. Groundwater tracing using fluorescent dyes is an appropriate method for investigating groundwater flow connections in karst settings. The use of activated carbon samplers during both tracer studies was critical in identifying sampling stations that received small concentrations of the introduced tracer dyes.

\section{Reconnaissance}

Prior to both the 1995 and 2013 traces, a thorough field reconnaissance of the study area was performed (Figure 2). Reconnaissance methods consisted of traversing all accessible stream reaches in the study area where stream

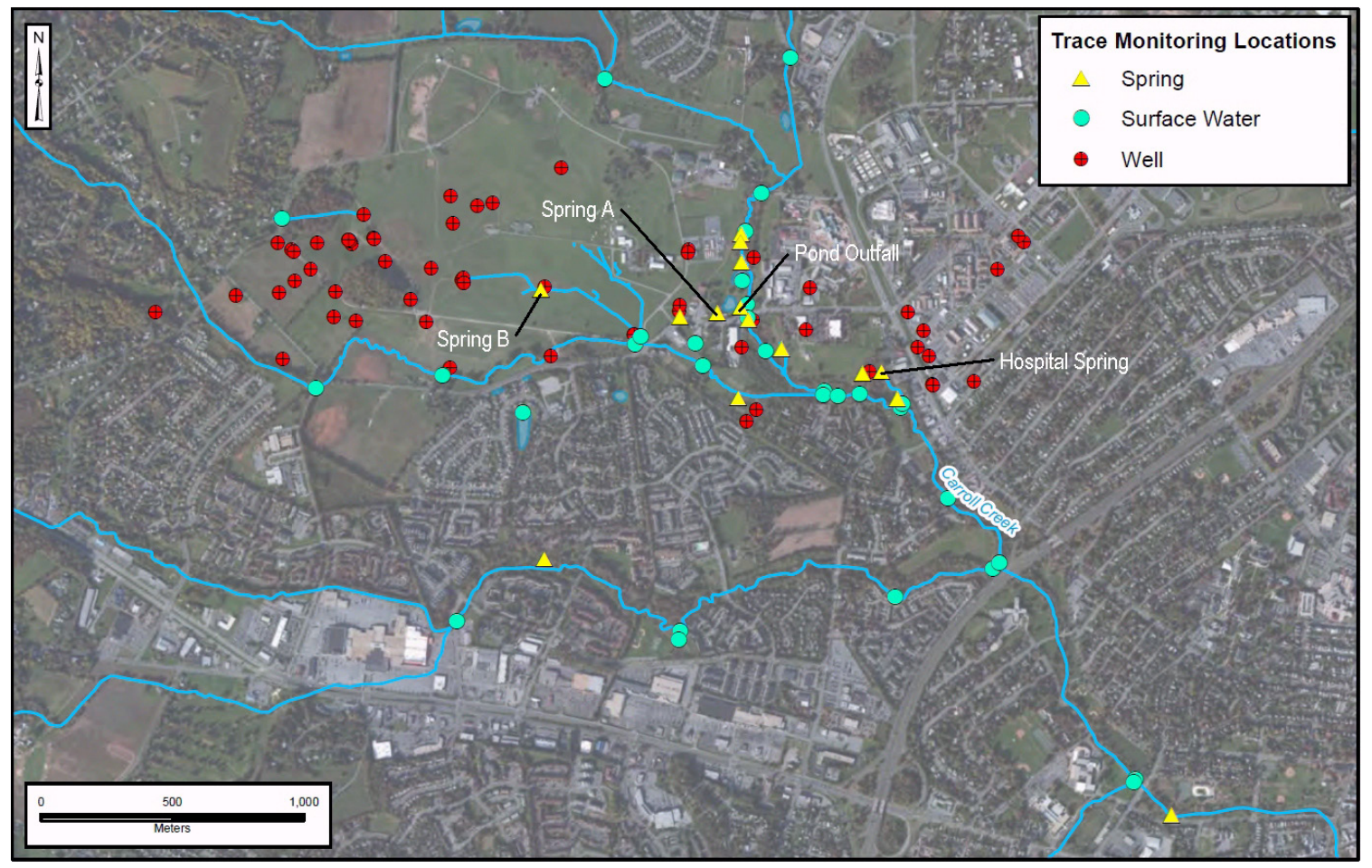

Figure 2. Map of study area and dye-monitoring locations. Note that several stream-monitoring locations from the 1995 study fall outside the figure to the southeast. 
elevations were at or below the elevation of the water table beneath planned dye-introduction points. For ponds, the perimeter of the pond was reconnoitered. Springs and other points of focused discharge (e.g., pond outfalls) were identified and mapped. For the 2013 study, water parameters (temperature, $\mathrm{pH}$, and conductivity) were measured with a field meter in both the discharging water and in the stream itself upstream of the discharge feature. Where feasible, the team estimated the approximate discharge rate of the feature.

\section{Tracer Dyes}

Three different dyes were used in two separate studies discussed in this paper. These dyes were fluorescein (Acid Yellow 73, Color Index 45350), eosine (Acid Red 87, Color Index 45380), and rhodamine WT (Acid Red 388 , no Color Index Number). The fluorescein and eosine were powdered dye mixtures consisting of $75 \%$ dye and $25 \%$ diluent. The rhodamine WT used was a liquid consisting of $20 \%$ dye and $80 \%$ diluent. These dyes are environmentally safe (Smart 1984, Field et al. 1995) and pose no risk to humans, livestock, or to aquatic life in the concentrations used in professionally directed groundwater tracing work. These dyes are among the most detectable of the commonly used fluorescent tracer dyes. They can be adsorbed onto activated carbon samplers for cumulative sampling or detected in water samples.

\section{Sampling for Tracer Dyes}

Both activated carbon samplers and water samples were collected during the two studies. Primary reliance for identifying dye detection sites was placed upon the activated carbon samplers. They are fiberglass screen wire packets loosely filled with 4.25 grams of laboratorygrade activated coconut shell carbon. These samplers adsorb, retain, and accumulate the tracer dyes. After being in place for one-to-two weeks (the typical sampling intervals during the two studies) the samplers routinely yield dye concentrations in the eluting solution that are at least one, and often two, orders of magnitude greater than the mean dye concentrations in the sampled water during the same period. The magnification factor tends to be greater for springs than for monitoring wells because of better circulation of dyed water around carbon particles. Carbon samplers are ideal for identifying points to which the tracer dyes move and for minimizing the amount of dye needed for credible traces. Water samples are valuable because they provide dye concentrations at known times and can permit mass balance calculations.

All samples were analyzed by the Ozark Underground Laboratory, Inc. (OUL) in Protem, Missouri. All sample collection and analysis procedures followed established OUL protocols (Aley and Kirkland, 2011).

\section{Tracer Study}

The groundwater tracing study was conducted from May to early October, 1995. Three different tracer dyes were introduced in different areas on June 7, 1995:

- $\quad 3.18 \mathrm{~kg}(7 \mathrm{lbs})$ of eosine dye were introduced into each of two Epikarstic Dye Introduction Points (EDIPs). EDIPs are borings that bottom in the epikarstic zone (approximately 7-15 m [23-50 ft] below grade) and are designed for introducing dye and water. EDIPs 1 and 2 were used for introducing the eosine dye and bracketed a former waste disposal area in the southwestern part of the study area. Using two EDIPs to bracket a relatively small waste area is an effective approach for identifying all the points to which contaminants from the waste area may flow.

- $\quad 2.27 \mathrm{~kg}(5 \mathrm{lbs})$ of fluorescein were introduced into each of EDIPs 3 and 4. These EDIPs were located in the northwestern portion of the study area and bracketed a second former waste disposal area.

- $4.54 \mathrm{~kg}$ (10 pounds) of rhodamine WT were introduced into a sinkhole where an intermittent surface stream terminated (called EDIP 5). It is in the west central portion of the study area, generally north of the eosine introduction locations and southwest of the fluorescein introduction locations2.

Approximately 9,500 liters (2,500 gallons) of water were introduced into each of the five locations following the dye introduction. The water was slowly discharged from poly tanks temporarily located adjacent to each EDIP.

A total of 139 sampling stations were monitored. Background sampling was conducted at most stations for three weeks prior to dye introductions. The background sampling identified some small emission fluorescence peaks in or near the wavelength range of fluorescein and the wavelength range of eosine (but not rhodamine WT) at a few sampling stations. In the case of fluorescein, these sampling stations were typically surface streams at points a short distance downstream of highways and parking areas. For eosine, the detections also occurred at a few surface water locations. It has been the experience of the OUL that such shoulders and small peaks are commonly attributable to algae or other aquatic plant materials. Sampling continued at most stations for 13 weeks after dye introduction; four additional weeks of sampling were conducted at selected stations.

\footnotetext{
${ }^{2}$ Note: this stream was not flowing at the time that the tracer was introduced.
} 


\section{Results}

Results of the 1995 study are depicted on Figure 3. Eosine was detected at 14 groundwater sampling stations: six monitoring wells and eight springs. Fluorescein was detected at two monitoring wells and six springs. Rhodamine WT was not detected at the any of the sampling stations during the study period. At that time, this was attributed to adsorption of this dye onto the aquifer matrix. Relative to the other dyes introduced, a smaller mass of rhodamine WT dye was used (based on the dye equivalent) due to an expectation that water and dye introduced into a sinkhole would be more readily connected to area springs than dye introduced into EDIPs.

Based on dye concentrations measured in water samples and flow rates of the springs, approximately $90 \%$ of the eosine and fluorescein that discharged during the study is estimated to have done so from Spring A, which has several discharge points ${ }^{3}$. The mean flow rate of this spring during the 1995 study period was about $13 \mathrm{~L} / \mathrm{s}$ (221 gal $/ \mathrm{min})$. The straight-line travel distance from the

${ }^{3}$ This study employed an ISCO automatic sampler that collected grab samples three times per day at Spring $A$. nearest eosine introduction point to Spring A was 1,425 $\mathrm{m}(4,675 \mathrm{ft})$; for fluorescein this distance was $1,340 \mathrm{~m}$ (3,350 ft.) Both eosine and fluorescein first arrived at Spring A 19 days after dye introduction. Fluorescein concentrations in water samples from Spring A continually increased during the 99 days after the first arrival of this dye at the spring. In contrast, the concentration of eosine increased throughout the first two months after first dye arrival at Spring A and then was relatively constant for the last month of sampling.

The 1995 dye tracing study demonstrated that the area to which shallow groundwater near the former disposal areas discharges is limited to springs that discharge along an approximately $670 \mathrm{~m}(2,200 \mathrm{ft})$ reach of Carroll Creek. During the study period $0.2 \%$ of the fluorescein and $0.9 \%$ of the eosine introduced into the groundwater system discharged from the springs.

\section{Tracer Study}

In the intervening years between the tracer studies a number of wells were drilled to further investigate groundwater beneath and downgradient of the former disposal areas. A number of these wells were completed

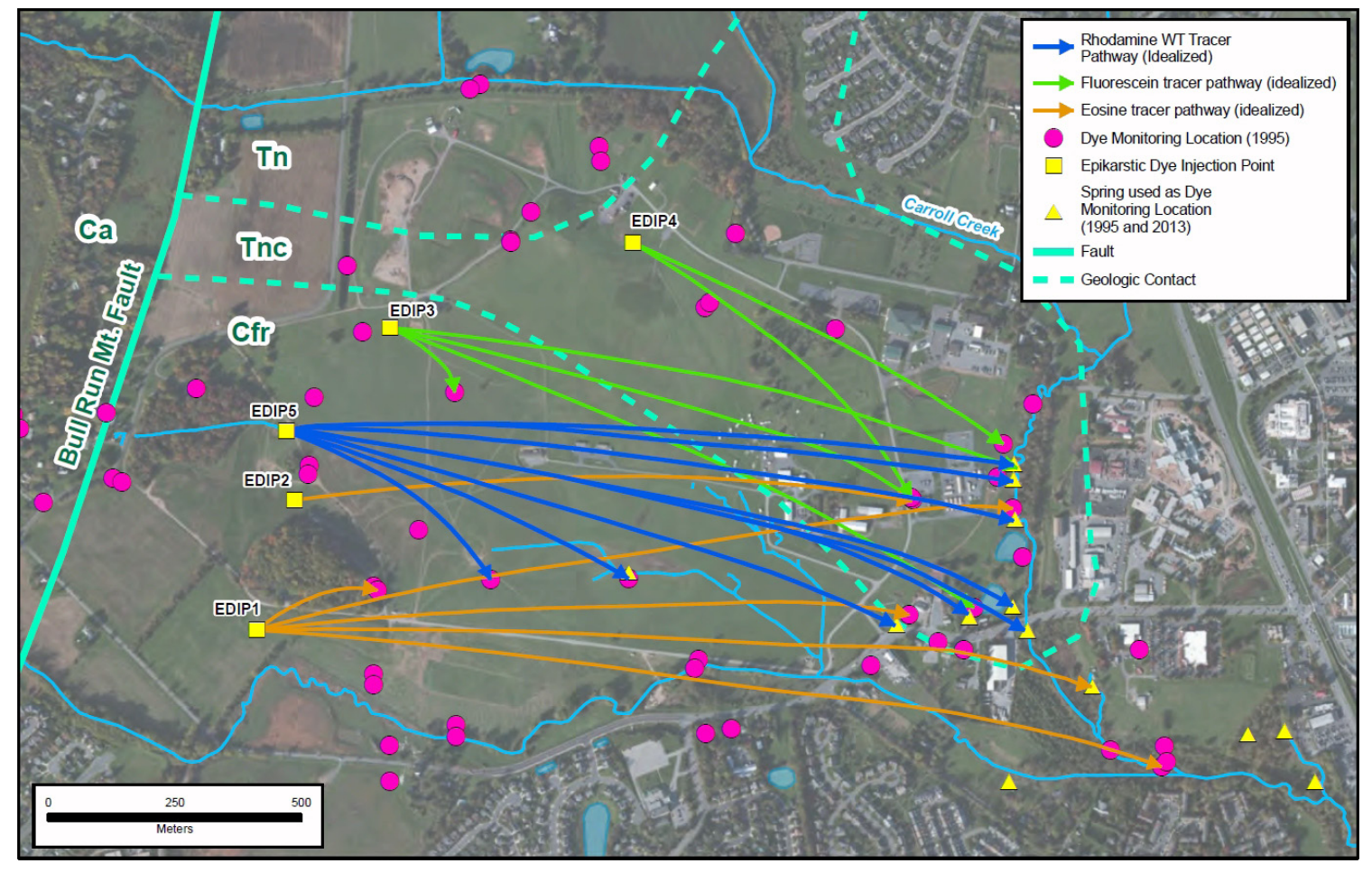

Figure 3. Results of 1995 tracer study. Rhodamine WT tracer pathways are based on 2013 tracer study results (see below); rhodamine WT was not detected during the 1995 trace. Tn = New Oxford Formation, Thc = New Oxford Conglomerate, $\mathrm{Cfr}=$ Rocky Springs Station Member of the Frederick Formation, Ca = Antietam Formation. Geology modified from Brezinski (2004b). 
at greater depths than wells that existed during the 1995 study. The additional drilling work revealed that, while the intensity of solution porosity (in terms of frequency and height) decreased with depth, sizeable cavities ${ }^{4}$ exist as deep as 96.5 to $96.8 \mathrm{~m}$ (316.5 to $317.5 \mathrm{ft}$ ) below the ground surface.

The objectives of the 2013 tracer study were to determine where the groundwater moving through this deeper solution porosity discharged and assess whether or not separate shallow and deep flow systems existed.

\section{Background Sampling}

Comprehensive background sampling was conducted for three weeks prior to introducing tracer dyes for the 2013 study. This sampling detected small concentrations of residual fluorescein, eosine, and rhodamine WT dyes. As discussed below, these detections are interpreted to represent dyes introduced during the 1995 tracing study ${ }^{5}$.

\section{Eosine}

Background fluorescence in the OUL's acceptable emission wavelength range of eosine was detected in samples from two wells and was attributed to eosine dye introduced for the 1995 tracer study (eosine dye was detected in these wells, post injection, during the 1995 study). Eosine persisted in these wells throughout the 2013 tracer study.

Eosine was also detected during background sampling at Spring B and at a location named "Pond Outfall". Water from this latter location is derived from several springs including Spring A. These background eosine detections represent residual dye from the 1995 tracer study.

\section{Rhodamine WT}

Residual concentrations of weathered rhodamine WT from the 1995 study were detected in activated carbon samplers from eight springs and one well during background and routine sampling for the 2013 tracer study (Figure 3). In total, there were 98 activated carbon samplers that were positive for weathered rhodamine WT dye. The mean dye concentration in the elutants from those samplers was $2.00 \mu \mathrm{g} / \mathrm{L}$ and concentrations ranged from 0.482 to $5.70 \mu \mathrm{g} / \mathrm{L}$. The OUL's detection limit for rhodamine WT in carbon sampler elutants is $0.170 \mu \mathrm{g} / \mathrm{L}$. No weathered rhodamine WT was detected in water

${ }^{4}$ i.e., $\geq 0.3 \mathrm{~m}(1 \mathrm{ft})$.

${ }^{5}$ After the 1995 study, it was learned that fluorescein had been disposed along with other wastes in one of the disposal areas. As a result, we do not discuss the background detections of fluorescein because its source is uncertain. samples because concentrations were below the 0.015 $\mu \mathrm{g} / \mathrm{L}$ detection limit for this dye in water.

The OUL's normal acceptable emission wavelength range for rhodamine WT in elutant samples is 565.2 to 571.8 nanometers $(\mathrm{nm})$. Twenty-one of the elutant samples (21 percent of the samples where rhodamine WT was detected) had fluorescence peaks in this acceptable range. The mean measured emission fluorescence peak for the 98 samples was $563.9 \mathrm{~nm}$ and the range was from 560.0 to $567.0 \mathrm{~nm}$. In the OUL's experience, emission fluorescence peaks for rhodamine WT are often slightly shorter than the normally acceptable wavelength range at low dye concentrations and when the dye has been in the ground for periods of several months or longer. In this case the rhodamine WT had been in the ground for 18 years. The cause of this behavior is uncertain, but may be related to the physical nature of rhodamine WT. Specifically, previous studies have shown tracer-grade rhodamine WT to contain two fluorescent isomers (Hofstraat et al. 1991; Shiau et al. 1993; Sutton et al. 2001). These isomers exhibit different emission spectra and sorption kinetics. In sand column experiments, Sutton et al. (2001) found one isomer to sorb more strongly than the other.

Rhodamine WT is also subject to alteration through deaminoalkylation (Kass 1998). This alteration shortens the wavelength of emission fluorescence peaks. This is an occasional problem at waste sites where emission fluorescence peaks for weathered rhodamine WT may be even shorter than those encountered in this study. The decreases in emission peak wavelengths occur both in water and in the elutant from carbon samplers, and typically increase with time.

\section{Tracer Introduction}

Following the background study, eosine and fluorescein dyes were introduced into deeper portions of the aquifer:

- On May 21, 2013, $6.8 \mathrm{~kg}$ (15 lbs) of fluorescein dye was introduced into Well X, constructed in the Frederick Formation with a screened interval of $95.4 \mathrm{~m}$ to $100.0 \mathrm{~m} \mathrm{(313} \mathrm{to} 328 \mathrm{ft}$ ) bgs. The target interval was a void at 96.5 to $96.8 \mathrm{~m}$ (316.5 to $317.5 \mathrm{ft}$ ) bgs. This is viewed as a deep well.

- On May 22, 2013, 10.4 kg (23 lbs) of eosine dye was introduced into Well Y, constructed in the Frederick Formation with a screened interval from 42.7 to $47.2 \mathrm{~m}$ (140 to $155 \mathrm{ft}$ ) bgs. During well construction a fracture was noted in this well at $45.7 \mathrm{~m}$ (150 $\mathrm{ft})$ bgs. This is viewed as an intermediate-depth well. 
Approximately 5,700 L (1,500 gal) of water were introduced into each of the wells following the dye introduction to flush the dye out of the well bore and into the groundwater system. The water was introduced through a tremie pipe at a rate that maintained less than $3.3 \mathrm{~m}$ (10 $\mathrm{ft}$ ) of head rise in the well.

A total of 127 stations were sampled during the 2013 study. Sampling stations consisted of monitoring wells, springs, streams, ponds, and some private wells. Samples were collected at most sampling stations for over six months following dye introductions. An additional three months of sampling were conducted at selected stations in the southeast portion of the study area.

\section{Results}

Results of the 2013 study are depicted on Figure 4. Eosine, introduced into the intermediate-depth well, was detected at 17 groundwater monitoring sites; 11 wells and six springs. The first arrival times for dyes at the wells ranged from less than eight days to about 155 days. The first arrival times for eosine dye at these springs ranged from about 19 days at Spring B to about 61 days at all other springs.

The mean straight-line travel rate for the first arrival of eosine at the monitoring wells was $15.6 \mathrm{~m} / \mathrm{d}(51.1 \mathrm{ft} / \mathrm{d})$. The mean straight-line travel rate for the first arrival of eosine at Spring B was $51.2 \mathrm{~m} / \mathrm{d}(168 \mathrm{ft} / \mathrm{d})$, while it was $27.9 \mathrm{~m} / \mathrm{d}(91.5 \mathrm{ft} / \mathrm{d})$ to the remaining, more distant springs.

Fluorescein, introduced into the deep well was detected at five wells and Spring A. The estimated mean straightline travel rate for the first arrival of the dye at the wells was $3.2 \mathrm{~m} / \mathrm{d}(10.5 \mathrm{ft} / \mathrm{d})$. The estimated mean straightline travel rate for first arrival of fluorescein at Spring A was $9.3 \mathrm{~m} /$ day $(30.4 \mathrm{ft} / \mathrm{d})$.

During the 2013 study period $0.01 \%$ of the fluorescein and $0.1 \%$ of the eosine introduced into the groundwater system discharged from the associated springs.

\section{Discussion}

The karst literature is replete with information on tracer studies conducted in karst aquifers that fall near the "conduit" end member of the conduit flow-diffuse flow continuum. These aquifers typically have near-ideal locations to inject tracers directly into the conduit porosity, and a significant proportion of the tracer mass moves relatively rapidly through the aquifer, generating what can be considered "classic" breakthrough curves at springs where dye discharges. Such curves exhibit a clear leading edge, peak concentration, and trailing edge of the tracer, and the travel times to each are reasonable in the context of field tracer studies - that is, the time between

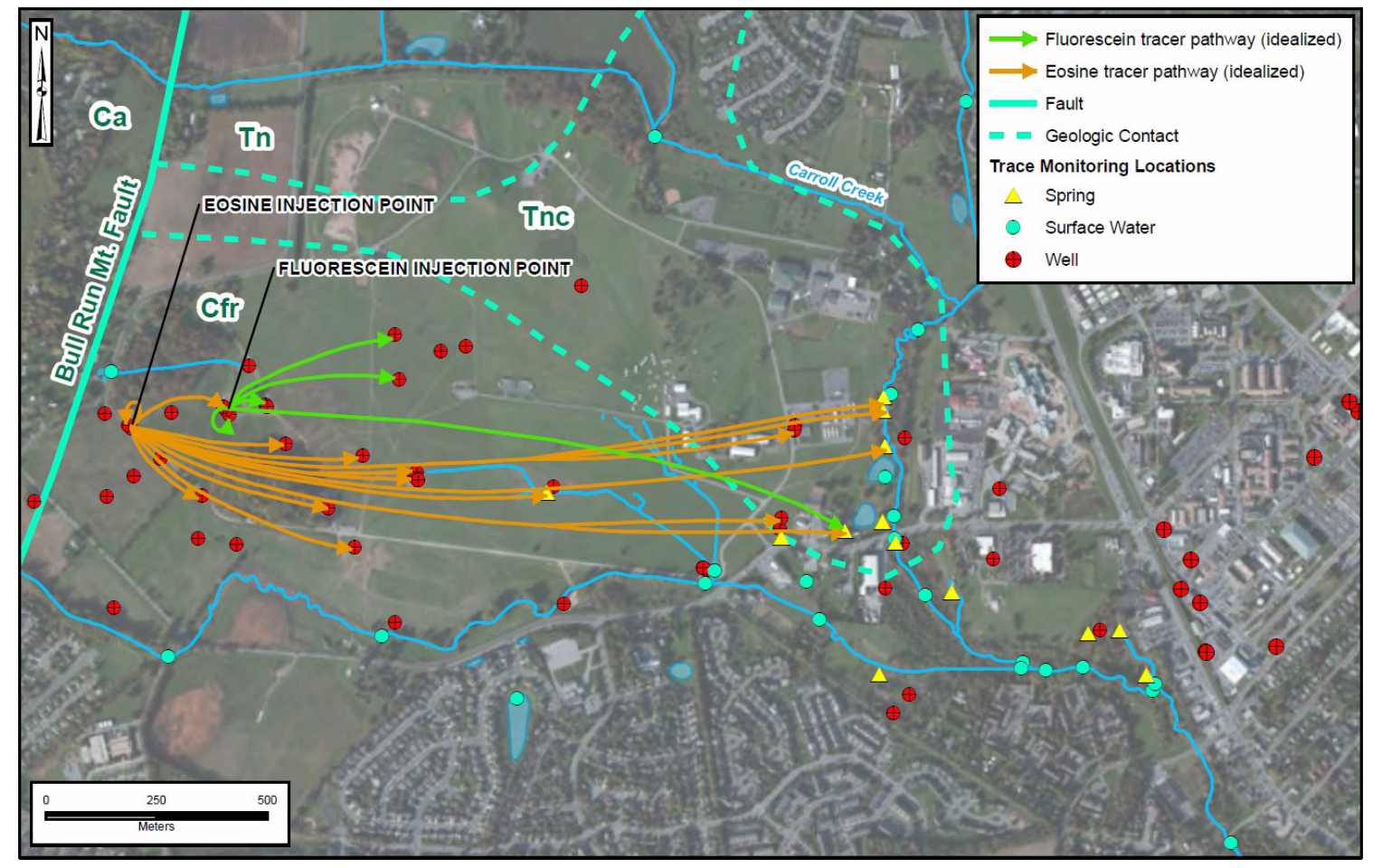

Figure 4. Results of 2013 tracer study. 
the leading edge and trailing edge of tracer is on the order of days to perhaps several months.

Less-well documented are tracer studies conducted in aquifers that exhibit an appreciable component of diffuse flow. In these aquifers, flow pathways may be poorly integrated or developed, more convoluted, and/or more occluded with clastic sediment. In our experience, such conditions are not uncommon in the folded and faulted carbonates of the Piedmont and Valley and Ridge Provinces. In such aquifers, tracer may remain in the aquifer for many years (Quinlan et al. 1990; Quinlan and Ray 1991; Quinlan and Ray 1992). As a result, tracer travel times can be prolonged, resulting in extended times between the leading edge and trailing edge of tracer and a significant flattening of breakthrough curves.

Figure 5 shows the breakthrough curves for fluorescein and eosine at Spring A during four months of the 1995 tracing study. The curves are based on three composite water samples per day with each composite containing three individual samples. Based on fourteen samples and their duplicates, the mean relative percent difference (RPD) values were $2.8 \%$ for fluorescein and $4.0 \%$ for eosine. Variations in dye concentrations from one sample to another are substantially greater than the RPD values; the cause of these variations is unknown. As can be seen in Figure 5, the time to reach the trailing edge of tracer, particularly for fluorescein which does not appear to have reached its peak concentration, could be on the order of several months to years.

The data collected during the two tracer studies described in this paper demonstrate that this aquifer contains an appreciable amount of stored water and exhibits a significant component of diffuse flow. Furthermore, these data lead to several useful findings.

\section{Utility of Activated Charcoal Samplers}

Activated charcoal samplers have proven their utility in tracing studies for many years. Their ability to accumulate tracer dyes allows detection of dyes where their concentration in water may be below detection limits in grab samples of the water. Our data show that, in aquifers with a significant component of diffuse flow, their use can significantly enhance the outcome of a tracer study. For the 1995 trace, 30 wells were sampled. Eosine was detected in carbon samplers from five of them and also in water samples from two of the five. Fluorescein was detected in carbon samplers from two of them and also in water samples from one of the two. A total of 10 springs were sampled. Eosine was detected in carbon samplers from eight of them and also in water samples from six of the eight. Fluorescein was detected in carbon samplers from six of them and also in water samples from four of the six.

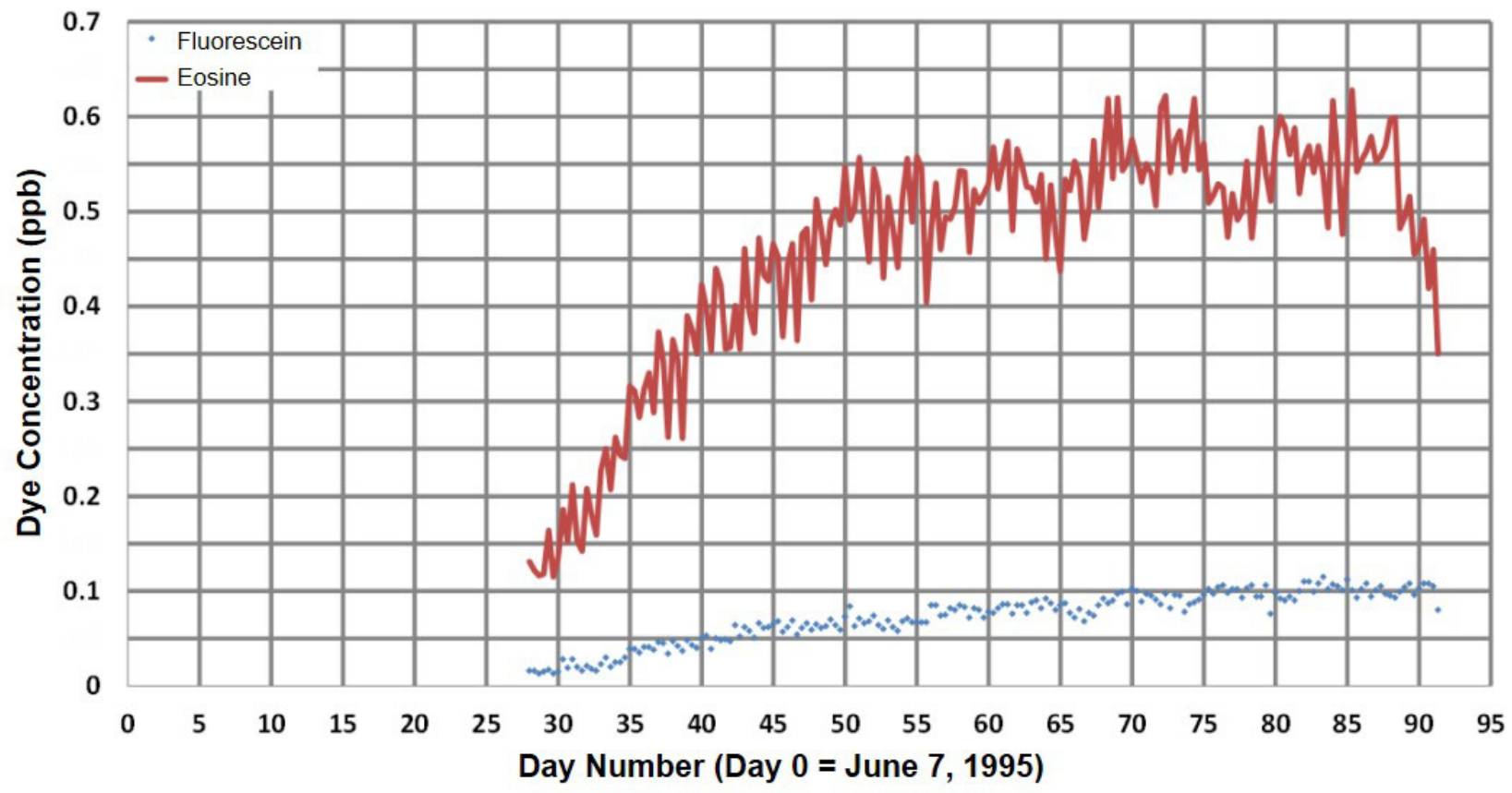

Figure 5. Breakthrough curves for fluorescein and eosine in water samples from Spring A - June 7 (introduced) to September 8, 1995. These dyes were first detected in carbon samplers deployed from June 23 to 29 - estimated first arrival = June 26 (Day 19). 
For the 2013 tracing 32 wells were sampled. Eosine was detected in carbon samplers from 11 of them and also in water samples from 5 of the 11. Fluorescein was detected in carbon samplers from five wells and also in water samples from four of the five. A total of nine springs were sampled. Eosine was detected in carbon samplers from six of these and also in water samples from two of the six. Fluorescein was detected in carbon samplers from two of the nine springs. Water samples from the same two springs also contained fluorescein.

Based on the above data it is clear that many dye-detection locations would have been missed if activated carbon samplers had not been used.

\section{Dye-Residency Time and Aquifer Storage Ca- pacity}

Results of this study demonstrate that in this aquifer, tracer dyes were largely sequestered and remained at detectable concentrations for at least 18 years. Remnants of eosine and rhodamine WT dyes from the 1995 tracing were found during background sampling prior to dye introductions for the 2013 tracing.

Small concentrations of rhodamine WT were detected during 2013 in carbon samplers from eight of the nine sampled springs and in carbon samplers from one of the monitoring wells. None of the water samples from these stations contained detectable concentrations of rhodamine WT. This finding further demonstrates the utility of the activated carbon samplers used in this study. The percentages of introduced dyes masses discharged from springs draining the aquifer during each of the two study periods $^{6}$ (Table 1 ).

The very small percentages of introduced dyes detected in associated springs, and the presence of remnant dyes in the aquifer 18 years after their introduction, is consistent with the conclusion that much of the introduced masses of tracer dyes are detained within the aquifer and have not discharged from the associated springs; that is, the storage capacity of this aquifer for organic tracer dyes, and by extension organic contaminants, is large. It is reasonable to conclude that an appreciable portion of contaminants disposed within the study area and not removed during remediation are also detained within the aquifer.

\section{Aquifer Structure and Groundwater Movement}

The findings of the tracer studies, when combined with boring data from wells drilled in the study area, provide insight into the nature of solution porosity in the aquifer

${ }^{6}$ No rhodamine WT, introduced in the epikarst zone, was detected during the first study period. and its role in groundwater movement. There is a welldeveloped epikarst beneath the soil and, as expected, solution porosity decreases with depth (Figure 6). Despite this decrease, solutional cavities have been discovered as deep as 105.3 to $105.45 \mathrm{~m}$ (345.5 to $346 \mathrm{ft}$ ) below ground surface in the Frederick Formation. In the New Oxford Conglomerate, the deepest cavity penetrated spanned from 82.6 to $82.9 \mathrm{~m}$ (271 to $272 \mathrm{ft}$ ). Such deep porosity can be caused by meteoric waters. The steeply dipping beds of limestone of the Rocky Springs Station Member, interspersed with occasional beds of insoluble shale, can serve to focus aggressive water downward, particularly along bedding-plane fractures among beds of purer, more soluble limestone. Near-vertical joints or faults serve to link such penetrated bedding planes creating phreatic loops (Ford 1971; Ford and Ewers 1978).

It is clear from the tracer studies that the aquifer consists of one flow system with variable travel rates. In a similar setting in the Shenandoah Valley, located about $65 \mathrm{~km}$ (40 $\mathrm{mi}$ ) to the west of the study area, Doctor et al. (2011) found that the carbonate aquifer beneath the valley was karstified to depths exceeding $300 \mathrm{~m}(984 \mathrm{ft})$ and that springs in the region integrated flow through both shallow and deep flow paths.

An interesting observation from this study is that flow in the aquifer is not only integrated vertically within the Frederick Limestone; but also is integrated between the Frederick Limestone and the New Oxford Conglomerate. Dyes introduced in the Frederick Limestone discharged mainly from springs issuing from the New Oxford Conglomerate.

The estimated first-arrival groundwater velocities throughout the aquifer are appreciably slower than those typical of many karst aquifers, and the dyes dispersed more widely in the aquifer than is common in conduit-dominated karst aquifers. These facts indicate that conduit flow is subdued in this aquifer. Anecdotal observations from long-time residents of the area indicate that the flow of larger springs in the area is remarkably constant. Flows are not observed to increase dramatically in response to storms, and spring

\begin{tabular}{|l|l|}
\hline Eosine in epikarst zone (1995) & $0.9 \%$ \\
\hline Fluorescein in epikarst zone (1995) & $0.2 \%$ \\
\hline Eosine in intermediate depth zone (2013) & $0.1 \%$ \\
\hline Fluorescein in deep zone (2013) & $0.01 \%$ \\
\hline
\end{tabular}

Table 1. Percentages of introduced dyes masses discharged from springs draining the aquifer during each of the two study periods. 


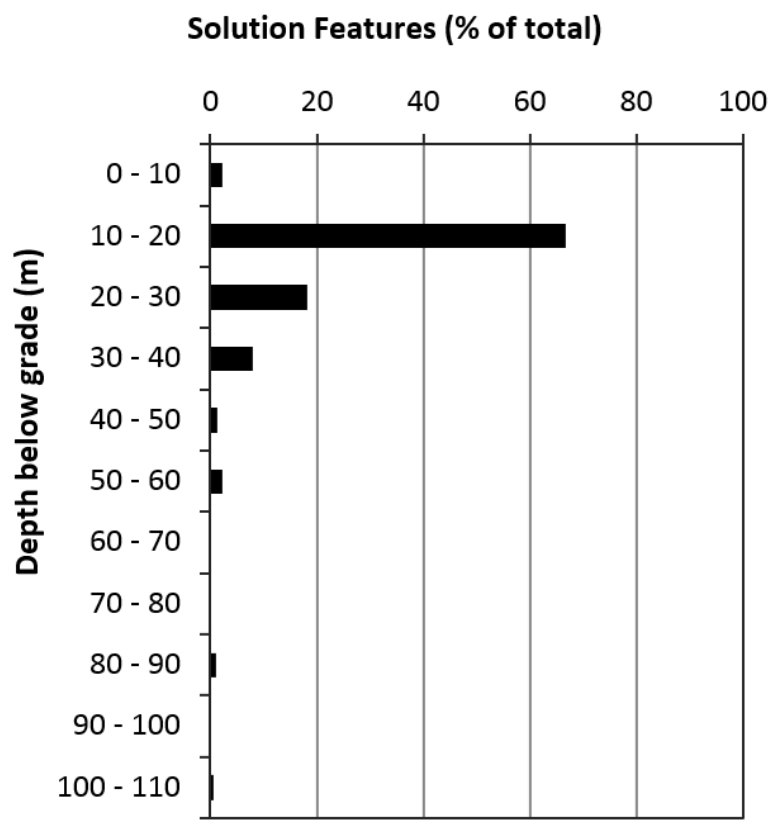

Figure 6. Depth distribution of solution-enlarged features observed in video logs. Percentages have been normalized to the footage of borehole logged in each depth interval. Data set consists of 30 solution features identified in 462 meters of video logging conducted at 17 boreholes.

water remains visibly turbid-free after such events. This suggests that aquifer recharge is primarily diffuse, and that flow velocities are too low to transport appreciable volumes of clastic sediments to springs.

The model for aquifer structure and groundwater flow described above also offers an explanation for the behavior of the rhodamine WT dye that was injected into the sinkhole in 1995. Since the rhodamine WT did not discharge during the 1995 study period, it is reasonable to conclude that the dye was detained in the aquifer and then slowly discharged over an extended period. It is clear that the flow paths followed by the rhodamine WT were longer, more complex, and less efficient than originally anticipated, and groundwater velocities were lower than anticipated.

The primary area of groundwater discharge from the karst aquifer is at one or more of the springs that discharge along an approximately $670 \mathrm{~m}(2,200 \mathrm{ft})$ reach of Carroll Creek $^{7}$. This is the case regardless of the depth at which ${ }^{7}$ A small amount of eosine from the 1995 tracing was detected at Hospital Spring, located about $230 \mathrm{~m}$ (750 ft) east-southeast of Spring A. tracer dyes were introduced. The 1995 tracer study included 139 sampling stations and sampling lasted for 13 weeks after dye introduction, and for 17 weeks at some selected locations. The 2013 tracer study included 127 sampling stations and lasted over six months and for an additional three months at selected locations. Both studies included many sampling stations at streams, springs, and wells located hundreds to several thousands of meters from the disposal areas. There are no data suggesting any significant discharge of dyed groundwater other than from the springs identified in this paper.

\section{Conclusions}

Tracing studies conducted 18 years apart elucidated aquifer structure and groundwater movement in the karst aquifer beneath the study area. Both the Cambrian Frederick Formation and the Triassic New Oxford formation have been karstified and act as one flow system to a depth of at least $100 \mathrm{~m}(328 \mathrm{ft})$. Flow velocities are sluggish by classic karst standards, attributed to flow pathways that are long, convoluted, and potentially occluded in places by clastic sediment. Diffuse flow, rather than conduit flow, plays a large role in the aquifer. As such, dye- and contaminant-residency times are long, on the order of decades. Eosine, rhodamine WT, and possibly fluorescein remained detectable in this aquifer 18 years after they were introduced.

Tracer studies conducted in this, and similar, aquifers may benefit from a longer duration, and greater introduced dye masses, than in aquifers with a greater component of conduit flow. The concentration of dyes discharged at springs can be expected to be relatively low; increasing the utility of activated carbon samplers. Had only grab samples of water been used in these two studies, many dye detections would have been missed.

\section{References}

Aley T, Kirkland S. 2011. Procedures and Criteria Analysis of Fluorescent Dyes in Water and Charcoal Samplers: Fluorescein, Eosine, Rhodamine WT, and Sulforhodamine B Dyes. Ozark Underground Laboratory. Protem, MO. [Updated 2011, Sep. 1; cited 2015 Mar 4]. Available from: http:// www.ozarkundergroundlab.com/Downloads/ Procedures\%20and\%20Criteria\%20110901.pdf

Brezinski DK, Reger JP. 2002. Stratigraphy-karst relationships in the Frederick Valley of Maryland. In: Kuniansky, EL, editor. U.S. Geological Survey Karst Interest Group Proceedings, Shepherdstown, WV. U.S. Geological Survey Water Resources Investigations Report 02-4174.

Brezinski DK. 2004a. Stratigraphy of the Frederick Valley and its relationship to karst development. 
Maryland Geological Survey, Report of Investigations No. 75.

Brezinski DK. 2004b. Geology of the Frederick Quadrangle, Frederick County, Maryland. Maryland Geological Survey Geologic Map, scale 1:24,000.

Brezinski DK. 2007. Geologic and anthropogenic factors influencing karst development in the Frederick Region of Maryland. Environmental Geosciences 14: 31-48.

Doctor DH, Farrar NC, Herman JS. 2011. Interaction between shallow and deep groundwater components at Fay Spring in the northern Shenandoah Valley karst. In: Kuniansky, EL, editor. U.S. Geological Survey Karst Interest Group Proceedings, Fayetteville, Arkansas. U.S. Geological Survey Scientific Investigations Report. p. 25-34.

Field MS, Wilhelm RG, Quinlan JF, Aley TJ. 1995. An assessment of the potential adverse properties of fluorescent tracer dyes used for groundwater tracing. Environmental Monitoring and Assessment 38: 75-96.

Ford DC. 1971. Geologic structure and a new explanation of limestone cavern genesis. Transactions of the Cave Research Group of Great Britain 13(2): 81-94.

Ford DC, Ewers RO. 1978. The development of limestone cave systems in the dimensions of length and breadth. Canadian Journal of Earth Science 15: 1783-98.

Hofstraat, MS, Vriezekolk G, Schreurs W, Broer GJAA, Winstok N. 1991. Determination of rhodamine WT in surface water by solid-phase extraction and HPLC with fluorescence detection. Water Research 25(7): 883-890.

Kass W. 1998. Tracing technique in geohydrology. Rotterdam, Netherlands: AA Balkema Publishers.

Nutter, LJ. 1973. Hydrogeology of the carbonate rocks, Frederick and Hagerstown Valleys, Maryland: Maryland Geological Survey Report of Investigations No. 19.

Quinlan JF, Ray JA. 1991. Application of dye-tracing to evaluation of a landfill site in a karst terrane: Rationale and an Appalachian case study (abs.). Geological Society of America, Abstracts with Programs 23(3): 54.

Quinlan JF, Ray JA. 1992. Ground-water remediation may be achievable in some karst aquifers that are contaminated, but it ranges from unlikely to impossible in most: Implications of long-term tracer tests for universal failure in goal attainment by scientists, consultants, and regulators. In: Quinlan JA and Stanley A, editors. Proceedings:
Conference on Hydrogeology, Ecology, Monitoring, and Management of Ground Water in Karst Terranes, (3rd, Nashville, TN). National Ground Water Association, Dublin, OH. p. 553558.

Quinlan JF, Ray JA, Elliot WG. 1990. Flowpath delineation, interpretation, and control in Pennsylvania karst terrane: Utilization of dyetracing to successfully accomplish and monitor these objectives (abs.). Geological Society of America, Abstracts with Programs 22(7): 371.

Shiau B, Sabatini DA, Harwell JH. 1993. Influence of rhodamine WT properties on sorption and transport in subsurface media. Ground Water 31(6): 913-920.

Smart PL. 1984. A review of the toxicology of twelve fluorescent dyes used for water tracing. National Speleological Society Bulletin 46: 21-33.

Southworth S. 1996. The Martic fault in Maryland and its tectonic setting in the central Appalachians. In: Brezinski, DK and Reger, JP, editors. Studies in Maryland geology, in commemoration of the centennial of the Maryland Geological Survey. Maryland Geological Survey Special Publication 3. p. 205-221.

Sutton DJ, Kabala ZJ, Francisco A, Vasudevan D. 2001. Limitations and potential of commercially available rhodamine WT as a groundwater tracer. Water Resources Research 37(6): 1641-1656. 
